\title{
Children-Friendly Assessment of Urban Green Open Space: The Case of Trunojoyo Park in Malang City, Indonesia
}

\author{
Anthea Putri Yasmin ${ }^{1 *}$, Novi Sunu Sri Giriwati ${ }^{2}$
}

\author{
${ }^{1,2}$ Department of Architecture, Faculty of Engineering, Universitas Brawijaya, Malang, Indonesia. \\ *Corresponding author. Email: who.riz.anthea@gmail.com
}

\begin{abstract}
UNICEF issued a policy in the form of CFCI (Child-Friendly City Initiative) as an effort to fulfill children's rights. Malang City has fulfilled the child-friendly indicators with a Madya rank, by meeting $60-70 \%$ of the Child-Friendly City Indicators. Malang City provides a playground for children in public spaces; one of them is in Taman Cerdas Trunojoyo. However, some problems can affect the child-friendliness of the park, such as poor maintenance of park facilities. Therefore, the question arises whether Taman Cerdas Trunojoyo is childfriendly or not? This research is conducted to get a result if Taman Cerdas Trunojoyo is child-friendly or not. This research is descriptive research. The method used is a mixed-method, which combines quantitative and qualitative methods with research respondents are parents/ guardians of children and children. Quantitative methods are used to determine respondents' perceptions of the quality of the object of study. The qualitative method is used to review the existing condition of the object of study through the researcher's perceptions and literature. Based on the analysis of the literature and 141 respondents, it was found that the child-friendly quality of Taman Cerdas Trunojoyo was good, according to parents/guardians of the children. While according to children's perception, the quality of child-friendly of the park is Decent. So, it can be said that Taman Cerdas Trunojoyo is child-friendly and suitable for children.
\end{abstract}

Keywords: Child-friendly, quality, playground

\section{INTRODUCTION}

Green Open Space is an elongated area/lane and/or cluster that is used more openly, where plants can grow, both natural and intentionally planted [1]. One type of green open space is a city park. There are 14 city parks in Malang, one of them is Taman Cerdas Trunojoyo, which is located on Trunojoyo Street, Malang City. The location is very strategic and can be accessed from anywhere with any vehicle or on foot. The park has playground facilities, fountain play area, seating area, and community reading park.

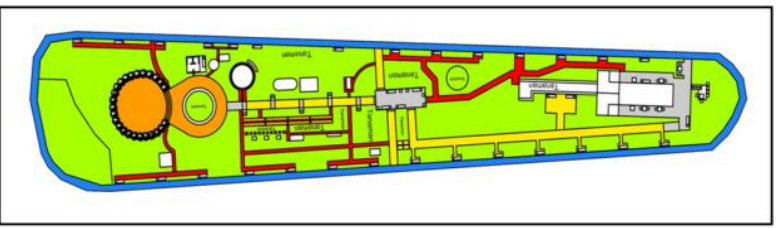

Figure 1 Taman Cerdas Trunojoyo siteplan

Malang City Government intends to increase the level of the city's child-friendliness. To realize Malang City as a ChildFriendly City, playgrounds have begun to be added to some parks. The government also cooperates with companies through the Corporate Social Responsibility program to develop the city. One of which is by providing playgrounds in city parks. Malang City has achieved the Child-Friendly
City award with the implementation of child-friendly city indicators reaches 60-70\% [2]. The eligibility of ChildFriendly City is evaluated by the Child-Friendly City Indicators. There are 31 Child-Friendly City indicators. One of them is "there are facilities for creative and recreational activities that are child-friendly, outside of school, and accessible to all children". One way to fulfill this indicator is by providing playgrounds.

A city park that facilitates children's play activities must be able to meet the needs of children of any kind. However, there are several problems encountered in the park, such as the park facilities is not disabled-friendly enough and can be dangerous for children. Based on the phenomena, the author is interested in evaluating the child-friendliness quality of Taman Cerdas Trunojoyo.

\section{THEORETICAL FRAMEWORK}

\subsection{Open Space}

Open space is a large space in the city that consists of green and nongreen open space [1]. It provides a space for movement, communication nodes, and public space for play and leisure [3]. Open space is formed because of the needs of a place to meet or communicate with each other [4]. 
There are two types of open space based on the activity that occurs inside of it, which is active open space and passive open space. Active open space is an open space that has human activities inside it. The opposite of active open space is passive open space, an open space that has no human activity in it. Passive open space only acts as an area buffer or just for aesthetic purposes.

Open space has two constituent elements, which is the soft material and hard material. Soft element is an element that can give softness and life, elastic, and flexible (i.e., vegetation). Hard element is an element that can give the nature of an open space become rigid and giving a strong impression of a place (i.e., pavement ways).

\subsection{City Park as a Green Open Space}

A city park is an open space that is functioning as leisure, education, or other activity's space at the city level [1]. One of the means of the availability of open space in a city is to fulfill the needs of the community of a place to do leisure activities or sport. City parks can be used to do many social activities. It can be used as a green open space with leisure facilities, playgrounds, gardens, sports facilities, and sports areas with green space availability of $30 \%$. Park facilities should able to be accessed by everyone because it is a public green open space. The percentage of green open space availability in a city park is $70-80 \%$ of its total area [1]

\subsection{Child-Friendly Park}

The child-friendly park is a park that provides children needs of their activities. According to UNICEF [5], a childfriendly city is a city, town, or community in which the voice, needs, priorities, and rights of children are an important part of public policies, programs, and decision making. There are five clusters as the aspects of a childfriendly city, according to Permen. PPPA No. 12 Year 2011 [6]. One of it is the fourth cluster: education, leisure, and cultural activities. In the cluster, there are indicators to determine the score of the cluster. One of it says, "The availability of facilities for creative and recreational activities that are child-friendly, outside of school, and are accessible to all children."

Children have the right to have time to rest and make use of their free time to do creative things, such as art and cultural activities. It can be realized by providing a space for children to play and do recreational and creative activities. The availability of playgrounds in city parks can support the child-friendly quality of a city. Children's playground is a place designed for children to play freely to gain excitement, pleasure, and excitement as well as a means of developing their cognitive, social, physical, and emotional abilities [7].

A playground must be designed carefully so it can meet the needs of children's activities. The criteria of a playground designed are shown in Table 1.

Table 1 Qualitative results for park's play, leisure, and sports facilities.

\begin{tabular}{|l|l|}
\hline Criteria & \multicolumn{1}{|c|}{ Indicator } \\
\hline Safety & The physical condition of the playground facility does not allow/cause accidents to the user while being used \\
\hline Healthy & Free from things that can cause health problems in the short and long term \\
\hline Comfort & $\begin{array}{l}\text { Physical comfort: freedom of using playground facilities, and not disturbed in doing activities } \\
\text { Psychologist comfort: feeling safe from the surroundings and protected from a climate that can disturb the comfort }\end{array}$ \\
\hline Ease & All playground facilities can be used, understand, and reachable by all children \\
\hline Security & Free from any criminal acts and/or vandalism \\
\hline Beauty & Attractive visually, can encourage people to come and have its uniqueness and identity as a playground \\
\hline
\end{tabular}

Aside from playground needs, natural space can also be used as a playground too. A playground must be able to flow from one area to another, as open and simple as possible, which can encourage children to use their imagination and having a connection with nature. Natural material (i.e., water, sand, stone) can be used as a medium for children to play and learn as well.

\subsection{Child-Friendly Park Design Criteria}

The child-friendly park is important for fulfilling children's needs for playing and other activities. A good, safe, and comfortable playground are necessary. Based on the theoretical framework, it can be concluded that we can use four points as the criteria for child-friendly park design.

1. Accessibility:

Access to the park can be accessed easily for everyone from every kind to access the park and the facilities inside it.
2. Play, leisure, and sports facilities:

The availability of play, leisure, and sports facilities is needed to fulfill children's needs. These facilities can be used by children to make use of their leisure time to do various activities of art, culture, sport, and other activities.

3. Amenities: Amenities can be a complement facility to support visitors doing their activity inside the park.

4. Natural space:

The availability of natural space can be a support for children to develop their skills.

\section{RESEARCH DESIGN}

This research is using an evaluation research approach, which attempts to determine whether a program or policy is successful or able to achieve its goals and objectives [8]. 
The evaluation is presented using the descriptive method, with the main purpose to provide a description using words or numbers about a situation, social, or relationship [8]. This research is using a combined research method (mixed methods) that combines quantitative and qualitative methods to form a new research method. With this method, researchers will be able to obtain a more comprehensive result [9]. The research design used in this paper is a concurrent triangulation design (Figure 2).

\subsection{Place and Time of Research Observation}

The observation takes place in Taman Cerdas Trunojoyo in Trunojoyo Street, Klojen, Malang City from Monday to Sunday, from afternoon to evening (01.00 PM-06.00 PM).

\subsection{Research Population and Sample}

The population of this research is visitors of Taman Cerdas Trunojoyo. Among the population, the sample is divided into two categories, which are parents/guardians of the children and children. The sample is chosen by nonrandom sampling with a purposive sampling technique.

\subsection{Research Variables}

Research variables are something that already decided by the researcher to be studied to gain information about the variable, then the conclusion of the research will be drawn
[9]. The aspects are used to evaluate the child-friendly quality of Taman Cerdas Trunojoyo. The aspects that will be used to evaluate the park's child-friendly quality is accessibility, play, leisure, and sports facilities, amenities, and natural space (Table 2).

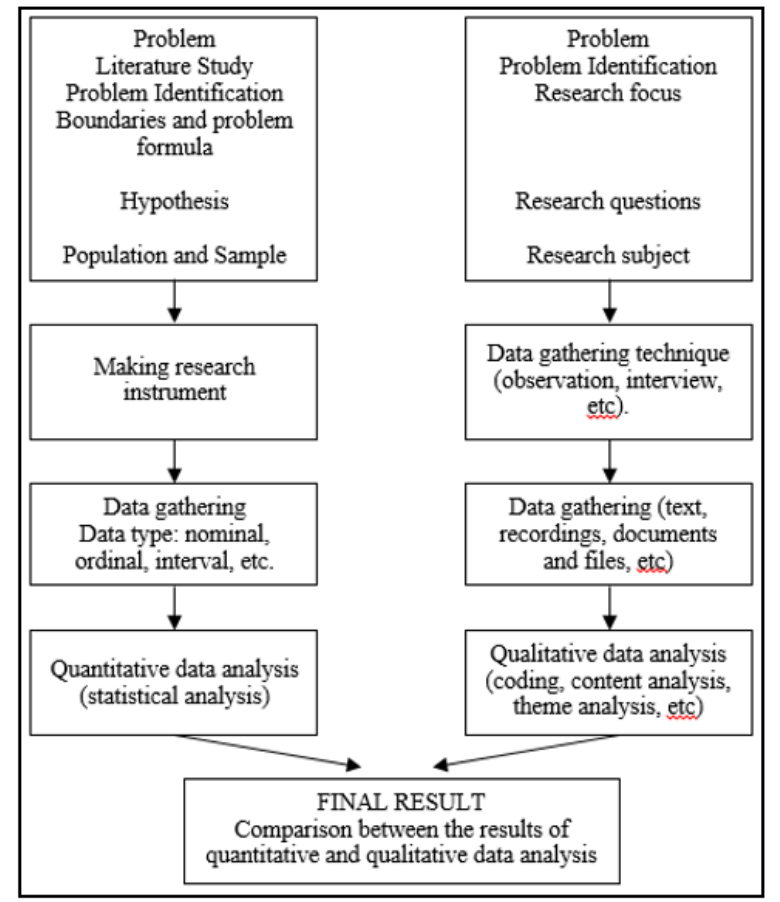

Figure 2 Concurrent triangulation research design diagram

Table 2 Research variables

\begin{tabular}{|c|c|c|}
\hline Aspect & Indicator & Variable \\
\hline \multirow{7}{*}{ Accessibility } & \multirow{5}{*}{$\begin{array}{l}\text { Ease and Security of } \\
\text { Park Accessibility }\end{array}$} & Playground's location security (A_1) \\
\hline & & Information system to park gate (A_2) \\
\hline & & Park accessibility and facilities for various groups (A_3) \\
\hline & & Pedestrian ways maintenance and comfortness (A_4) \\
\hline & & Pedestrian ways safety (A_5) \\
\hline & \multirow{2}{*}{ Parking Lot } & Parking lot availability (A_6) \\
\hline & & Parking lot security (A_7) \\
\hline \multirow{7}{*}{$\begin{array}{l}\text { Play, Leisure, and } \\
\text { Sport Facilities }\end{array}$} & \multirow{5}{*}{ Playground Facilities } & Children can practice social skills and confidence (FRKO_1) \\
\hline & & Physical safety of playground facilities (FRKO_2) \\
\hline & & Surfacing under playground facilities (FRKO_3) \\
\hline & & Educative nature of facilities (FRKO_4) \\
\hline & & Maintenance and comfort of playground facilities (FRKO_5) \\
\hline & \multirow{2}{*}{ Park Seating } & Seating facilities creates social interactions (FRKO_6) \\
\hline & & Maintenance of seating facilities (FRKO_7) \\
\hline \multirow{4}{*}{ Park Amenities } & \multirow{3}{*}{ Sanitation Facilities } & Availability of public toilets and washrooms (FP_1) \\
\hline & & Availability of trash can (FP_2) \\
\hline & & Maintenance and comfort of sanitation facilities (FP_3) \\
\hline & Park Seating Area & Seating area facilities as a place to gather and socialize (FP_4) \\
\hline \multirow{3}{*}{ Park's Natural Space } & \multirow{2}{*}{ Park Vegetations } & Comfort with vegetation that shades the park (RA_1) \\
\hline & & Maintenance of park's vegetation giving comfort (RA_2) \\
\hline & Nature as children area & Nature as the medium for learning and playing for children (RA_3) \\
\hline
\end{tabular}




\subsection{Data Collection Method}

The data collection method is divided according to each research method, namely, quantitative and qualitative data.

1. Quantitative Data, gathered using questionnaires. The questionnaire uses a Likert scale with a range of scales of one (Strongly Disagree), two (Disagree), three (Neutral), four (Agree), and five (Strongly Agree).

2. Qualitative Data, gathered by directly observing the park. The researcher observes the facilities and visitor's behavior in the park. Qualitative data is gathered with a camera, pen, and paper.

\subsection{Data Analysis Method}

The data analysis is divided according to each research method, which is by quantitative and qualitative methods.

1. Quantitative method, is used to understand respondents' perceptions of the child-friendliness quality of Taman Cerdas Trunojoyo. Quantitative data analysis uses several steps, namely mean score analysis, factor analysis, and regression.

2. Qualitative method, is used to compare the observations data with kinds of literature and the researcher's perception.

3. Mixed-Method. The research uses concurrent triangulation design by combining the analysis result to reach a conclusion whether the data is converging into one understanding or divided into different understandings.

\subsection{Data Synthesis Method}

After the data is analyzed, then the result will be synthesized. Data synthesis is performed by determining whether the analysis result per indicator will come under Poor, Decent, or Good for child-friendliness quality. The synthesis result will then be compared to each respondent group to find out if both groups have the same or different perceptions.

\subsection{Conclusion Drawing}

Conclusions are drawn from the final results of the analysis and synthesis of qualitative, quantitative, and combined analysis. After the conclusion has been drawn, then the design recommendation will be given.

\section{FINDINGS AND DISCUSSION}

Taman Cerdas Trunojoyo is a city park that is also a children's playground. This park is located on Trunojoyo Street, Klojen, Malang City. This park is equipped with play and sports facilities to support children's play needs. The park also has a reading room as an educational medium for children and other park visitors. Amenities found in this park are the rinse room, public bathroom, and a seating zone with a tent roof.

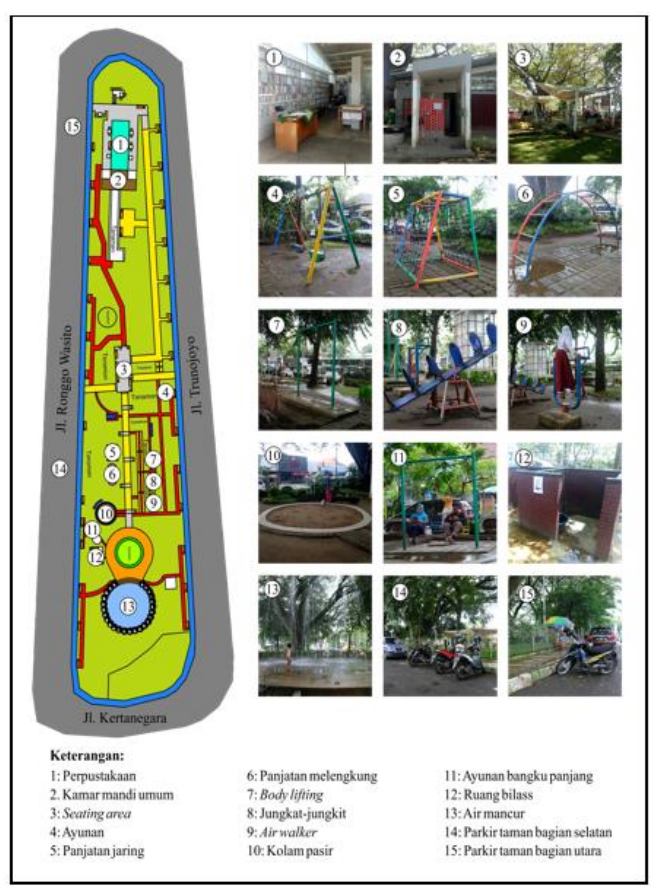

Figure 3 Facilities inside the park.

Referring to Detailed Spatial Plan (RDTR) of Malang 20162036 [10], the use of Taman Cerdas Trunojoyo space is included in the Green Open Space-1 sub-zone which is a green open space for urban parks and forests (Figure 4). The location can be easily accessed by both private vehicles and public transportation. There is a parking lot next to the park, so visitors do not need to walk far to reach the park.

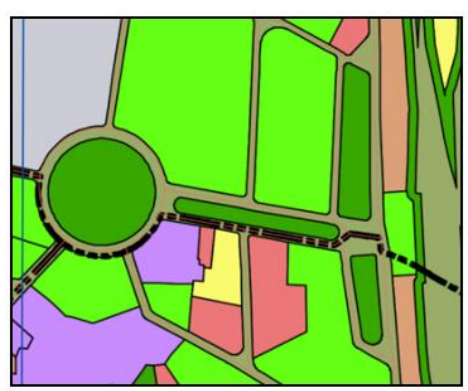

Figure 4 Zoning regulations of green open space for the city park [10]

\subsection{Respondent Demographics}

There are two groups of respondents of this research, which are parents/guardians of the children group and children group. There are 141 respondents gathered from both groups, with 76 respondents from parents/guardians of the children group and 65 respondents from the children group. 


\subsection{Qualitative Result}

Qualitative data is analyzed by comparing the data with kinds of literature and the researcher's perception. The literature used to analyze the data are theories and standards for playgrounds and parks.

\subsubsection{Park Accessibility}

The quality of the accessibility of the park gets a decent quality for child-friendliness. This is because the indicator variables do not fully meet the existing standards and theories. Two variables have a good quality (A_1 and A_6), three variables have decent quality (A_2, A_5, and A_7), and two other variables have bad quality (A_3 and A_4).

Table 3 Qualitative result for the park's accessibility.

\begin{tabular}{|c|l|c|}
\hline Indicator & \multicolumn{1}{|c|}{ Variable } & Quality \\
\hline \multirow{4}{*}{$\begin{array}{c}\text { Ease and } \\
\text { Security of } \\
\text { Park } \\
\text { Accessibility }\end{array}$} & Playground's location security (A_1) & Good \\
\cline { 2 - 3 } & $\begin{array}{l}\text { Information system to park gate (A_2) } \\
\text { Park accessibility and facilities for }\end{array}$ & Decent \\
\cline { 2 - 3 } & $\begin{array}{l}\text { Pedestrian ways maintenance and } \\
\text { comfortness (A_4) }\end{array}$ & Bad \\
\cline { 2 - 3 } & Pedestrian ways safety (A_5) & Decent \\
\hline \multirow{2}{*}{ Parking Lot } & Parking lot availability (A_6) & Good \\
\cline { 2 - 3 } & Parking lot security (A_7) & Decent \\
\hline
\end{tabular}

\subsubsection{Playground's location security (A_1)}

Park fence is already installed as a barrier to limit outside interaction towards inside and vice versa. The fence is also hard to be climbed by children. There are two park gates placed on the same side of the park. There are benches behind the playground facilities so parents/guardians of children can watch their children easily. The park layout is also separated into two areas, but the areas have not grouped the playground facilities based on the categories (i.e., age group and activity group). Therefore, the quality of this variable is Good and child-friendly.

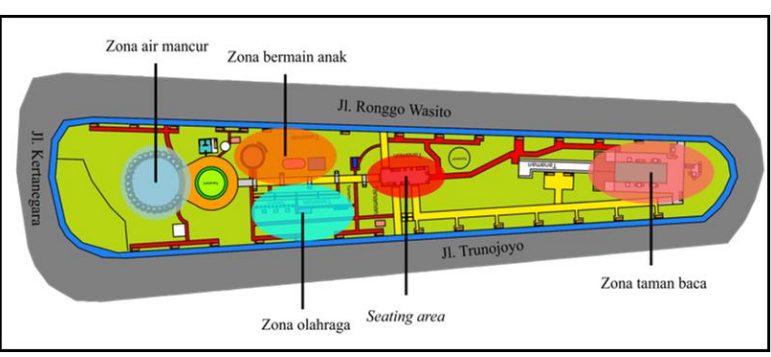

Figure 5 Park area zones.

\subsubsection{Information system to park gate (A_2)}

Park gate is given a different color, so it looks different from the fence. However, there is no specific detail for the gate, so the gate and the fence have the same shape (Figure 6).

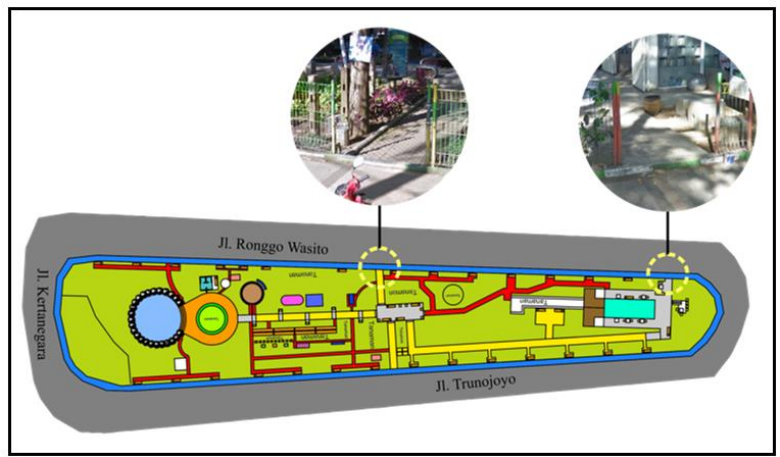

Figure 6 Park gate location and design

\subsubsection{Park accessibility and facilities for various groups (A 3)}

The availability of ramp inside the park is a few. There are only two ramps inside the park. The minimal amount of ramp availability can limit the movement of visitors with disabilities. Pedestrian ways also not disabled-friendly enough to be used by disabled visitors. This is because there is almost no street furniture to help the disabled move and access the park and the facilities. There is no specially designed playground facility for disabled children, so the disabled cannot freely use all playground facilities.

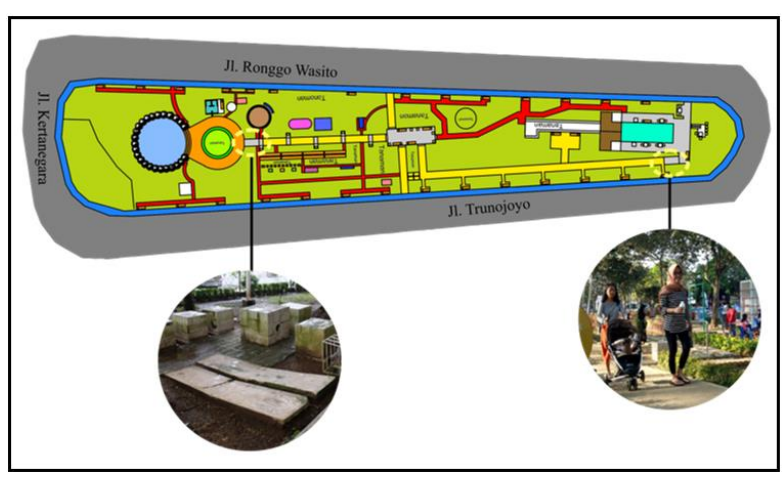

Figure 7 Park ramp

The availability of signage in the park is also minimal. There are signages available with rules and restrictions as the content of the signage. However, there is no signage to show the location for facilities in the park. This makes visitors sometimes did not know the availability of the amenities in the park. The visitor's self-awareness is also poor to keep the park clean and obey the rules in the park. 


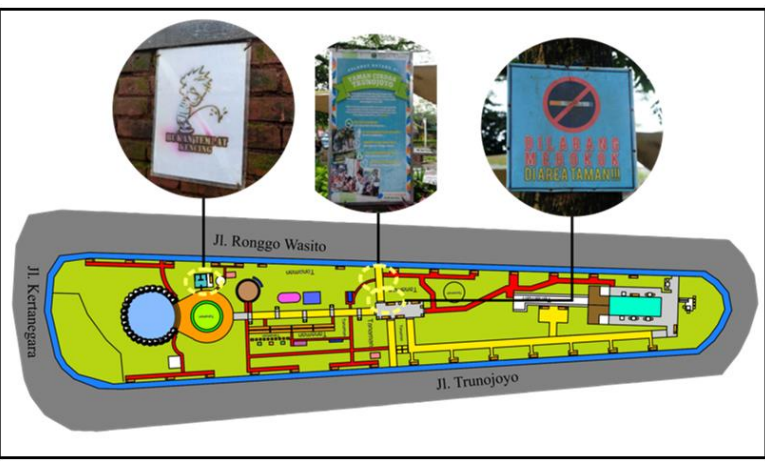

Figure 8 Park signage

\subsubsection{Pedestrian ways maintenance and comfortness (A 4)}

Pavement block design using the pavement block with holes in it. This can decrease the safety and comfort of visitors while walking in pedestrian ways. The level of pedestrian ways is also uneven, so when rain occurs, there are puddles everywhere, even in pedestrian ways.

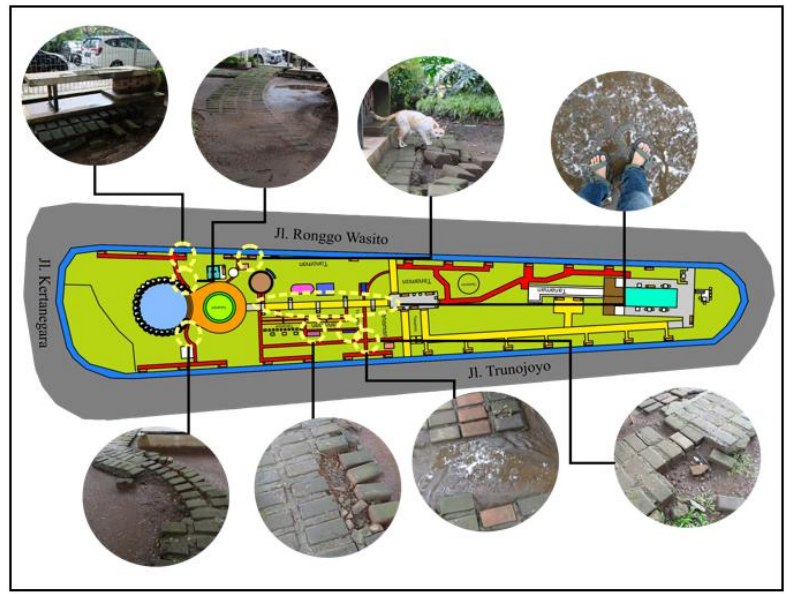

Figure 9 Broken pedestrian ways in the park

Some of the pedestrian ways segment are too narrow and does not meet the standards. Those segments have a width of $\pm 40-80 \mathrm{~cm}$, while the standards recommended the minimum of pedestrian ways width is $90 \mathrm{~cm}$, while the minimum width for the disabled is $150 \mathrm{~cm}$ [11].

\subsubsection{Pedestrian ways safety (A 5)}

The pedestrian ways are safe to be accessed anytime because there is lighting available during the night. However, the pavement block design has holes in it. This is unsafe and can make visitors tripped in the park because the holes will be hard to see.

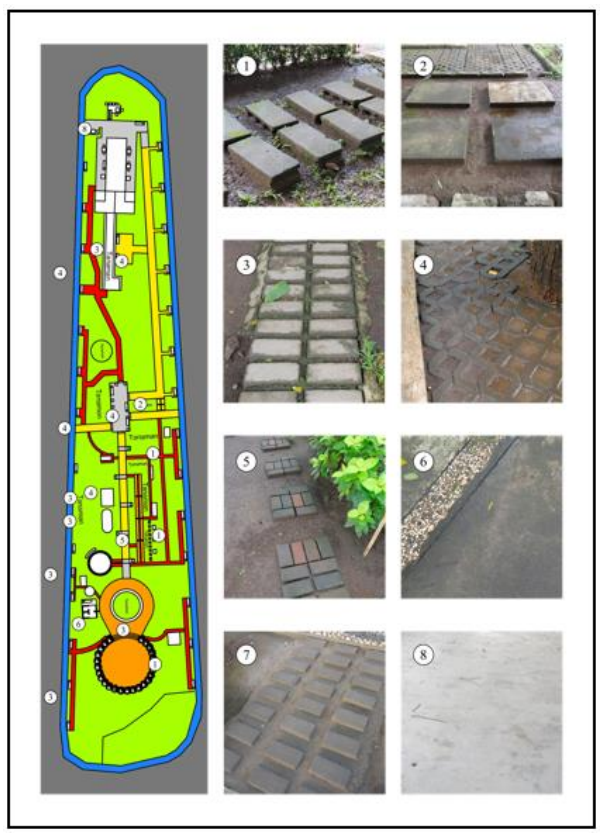

Figure 10 Types of pavement block designs in the park

\subsubsection{Parking lot availability (A_6)}

There is a parking lot located beside the park on Ronggo Warsito Street. The park is located near to park gates, so the visitors can easily access the park without having to walk far to reach the park.

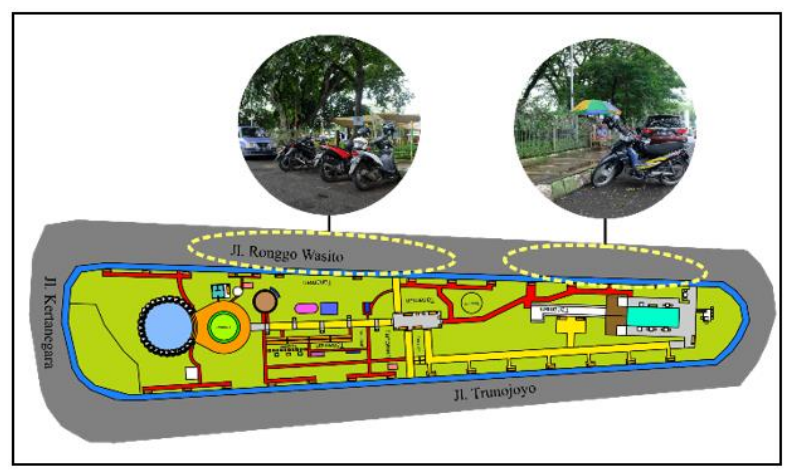

Figure 11 Park's parking lot

\subsubsection{Parking lot security $(A \quad 7)$}

The parking lot is on-street parking. This can affect the safety of the parking lot because the parking lot is located on a narrow road, with a road width of $10 \mathrm{~m}$ for two lanes. One side of the road is used for the parking lot, and the other side is used for street vendors. This left the remaining space for the vehicle to move only $6 \mathrm{~m}$. Parking officers guard each parking lot, but sometimes the officers did not guard the vehicle properly. 


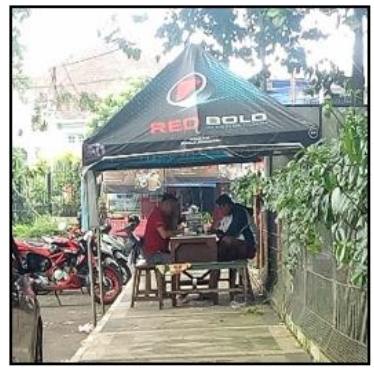

Figure 12 The parking officer

\subsubsection{Park's Play, Leisure, and Sport Facilities}

The quality of the play, leisure, and sports facilities of the park gets a decent quality for child-friendliness. This is because the indicator variables do not fully meet the existing standards and theories. Two variables have a good quality (FRKO_6 and FRKO_7), three variables have decent quality (FRKO_1, FRKO_2, and FRKO_5), and two other variables have bad quality (FRKO_3 and FRKO_4).

Table 4 Qualitative result for the park's play, leisure, and sport facilities

\begin{tabular}{|c|c|c|}
\hline Indicator & Variable & Quality \\
\hline \multirow{5}{*}{$\begin{array}{l}\text { Playground } \\
\text { Facilities }\end{array}$} & $\begin{array}{l}\text { Children can practice social skills and } \\
\text { confidence (FRKO_1) }\end{array}$ & Decent \\
\hline & $\begin{array}{l}\text { Physical safety of playground } \\
\text { facilities (FRKO_2) }\end{array}$ & Decent \\
\hline & $\begin{array}{l}\text { Surfacing under playground facilities } \\
(\text { FRKO_3) }\end{array}$ & Bad \\
\hline & $\begin{array}{l}\text { Educative nature of facilities } \\
\text { (FRKO_4) }\end{array}$ & Bad \\
\hline & $\begin{array}{l}\text { Maintenance and comforts of } \\
\text { playground facilities (FRKO_5) }\end{array}$ & Decent \\
\hline \multirow{2}{*}{$\begin{array}{c}\text { Park } \\
\text { Seating }\end{array}$} & $\begin{array}{l}\text { Seating facilities creates social } \\
\text { interactions (FRKO_6) }\end{array}$ & Good \\
\hline & $\begin{array}{l}\text { Maintenance and comforts of seating } \\
\text { facilities (FRKO_7) }\end{array}$ & Good \\
\hline
\end{tabular}

\subsubsection{Children can practice social skills and confidence (FRKO 1)}

Children can play freely using any playground facilities, but there is no playground facility specially designed for disabled children yet. Children can develop their social skills by asking other children to play swing, sand, and water fountain together. Children are also talking to their parents/guardians, asking about the vegetation, animals, and anything that happened inside the park. Children can develop their confidence by showing off their talent to their parents/guardians and other children. Nevertheless, sometimes the parents/guardians of children are too strict for children to do anything they want. This can affect the development of children to explore their skills more.

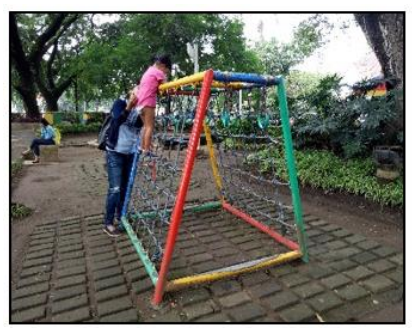

Figure 13 A mother holds her daughter while climbing

\subsubsection{Physical safety of playground facilities (FRKO 2)}

Based on the comparison between the existing condition of playground facilities and the standards, it is found that some of the playgrounds have not met the standards. According to Baskara [7], playground facilities' design must avoid a sharp angle and recommend the obtuse angle or curved corner. One of the swings have right angles on its corner, and this can be dangerous to children if it hits children's body or head. According to BS EN 1176, BS EN 1177 [12], and the U.S. Consumer Product Safety Commission [13], the playground facilities have already met the standards. However, the seesaw is not meeting the standards because of the tilt angle is too high.

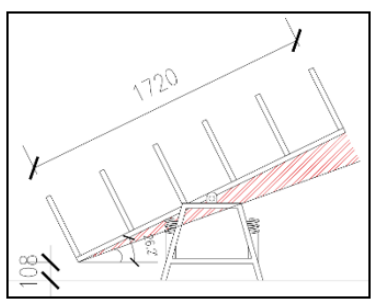

Figure 14 The seesaw's angle not meeting the standard

\subsubsection{Surfacing under playground facilities (FRKO 3)}

Some references suggest adding a protective surfacing below the playground facilities to protect children from severe trauma when they are falling off $[7,12,13]$. The surfacing used in this park is pavement blocks and earth, which cannot absorb the damaging impact when children fell off. This can be dangerous for children and considered not child-friendly.

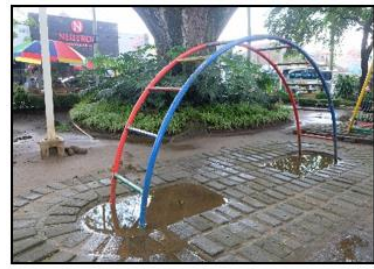

Figure 15 No protective surfacing in the park 


\subsubsection{Educative nature of facilities (FRKO_4)}

Playground facilities can also be a form of educative media for children to learn with fun. In Taman Cerdas Trunojoyo, some facilities can enhance children's creativity, imagination, and knowledge. Those facilities are playground facilities with natural elements as the play media, such as sand play area and water fountain play area. However, other facilities can only enhance children's motoric and sensory skills.

Aside from that, the types of playground facilities are also minimum of variance. This can prevent children from exploring their skills more. The educational facility's availability is only restricted to the reading park. The playground facilities itself is not educative enough for children to learn new things.

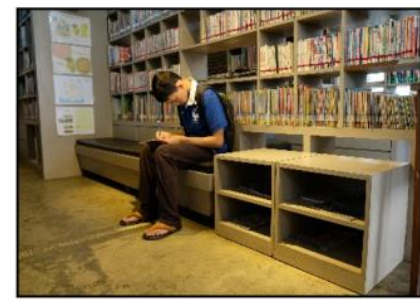

Figure $16 \mathrm{~A}$ boy is reading in the park library

\subsubsection{Maintenance and comforts of playground facilities (FRKO 5)}

The playground facilities mainly in good condition. There is a facility that cannot be used to full potential because it has broken, which is the air walker. Overall, the facility needs to be maintained regularly, so the facilities will not rust and break.

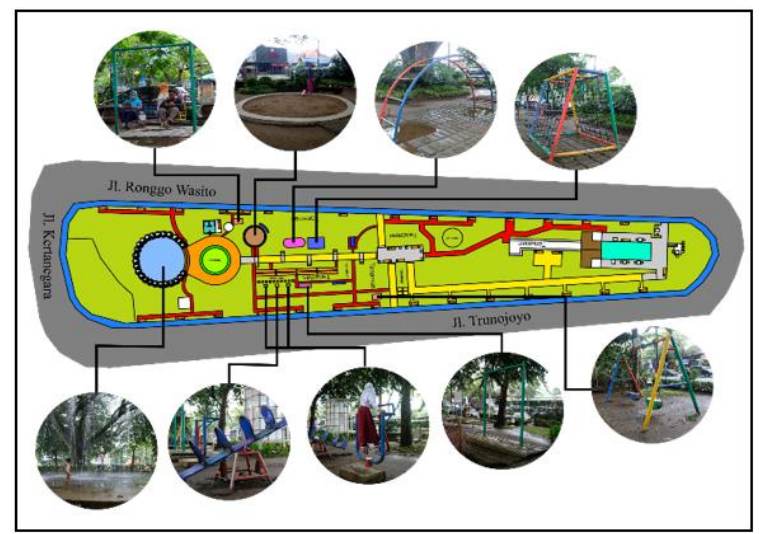

Figure 17 Playground facilities in the park

\subsubsection{Seating facilities creates social interactions (FRKO_6)}

Parents/guardians of children often sat together with other families. This creates interaction between parents/guardians and family as well. Aside from socializing with each other, they also supervise their children and the other.

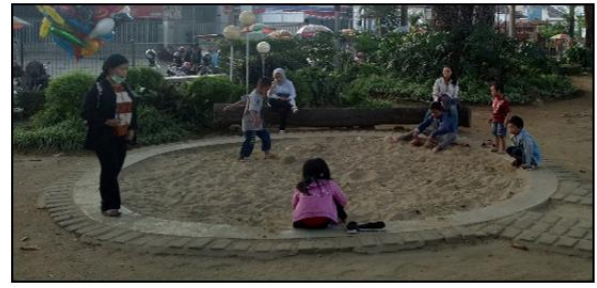

Figure 18 Parents/guardians of children supervising the children playing

\subsubsection{Maintenance and comforts of seating facilities (FRKO_7)}

The bench park, as the seating facility, is made from concrete and stone. Some of them made of wood. The bench is sturdy and meets the standards of Permen PU No. 03/PRT/M/2014 [11], which requires a bench to be made from sturdy material with long durabilities such as concrete and metal.

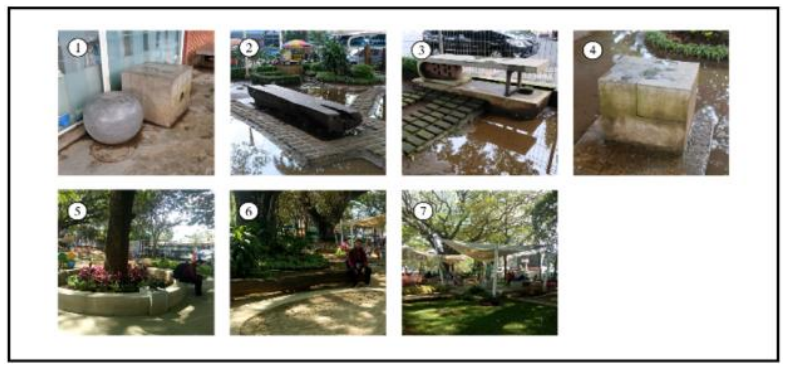

Figure 19 Types of seating in the park

\subsubsection{Park Amenities}

The quality of the amenities of the park gets good quality for child-friendliness. Therefore, it can be said that this indicator is child-friendly. Three variables have a good quality (FP_1, FP_2, and FP_4), one variable had decent quality (FP_3), and no variable have bad quality.

Table 5 Qualitative result for the park's amenities

\begin{tabular}{|l|l|l|}
\hline \multicolumn{1}{|c|}{ Indicator } & \multicolumn{1}{|c|}{ Variable } & Quality \\
\hline \multirow{3}{*}{$\begin{array}{l}\text { Sanitation } \\
\text { Facilities }\end{array}$} & $\begin{array}{l}\text { Availability of public toilets and } \\
\text { washrooms (FP_1) }\end{array}$ & Decent \\
\cline { 2 - 3 } & Availability of trash can (FP_2) & Good \\
\cline { 2 - 3 } & $\begin{array}{l}\text { Maintenance and comfort of sanitation } \\
\text { facilities (FP_3) }\end{array}$ & Decent \\
\hline $\begin{array}{l}\text { Park } \\
\text { Seating } \\
\text { Area }\end{array}$ & $\begin{array}{l}\text { Seating area facilities as a place to } \\
\text { gather and socialize (FP_4) }\end{array}$ & Good \\
\hline
\end{tabular}




\subsubsection{Availability of public toilets and washrooms (FP_1)}

Public toilets and washrooms are already provided in the park. The toilets are located behind the park library, while the washrooms are located near the water fountain play area. The washroom can be seen easily because the building can be seen directly. However, the public toilet is hidden behind the library park. No signage can tell visitors the toilet's location. This makes some visitors did not know the availability of public toilets inside the park.

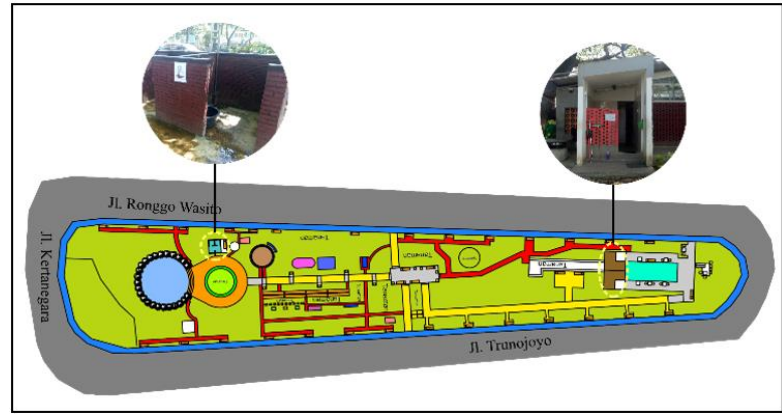

Figure 20 Location of the washroom and public toilet

\subsubsection{Availability of trash can (FP_2)}

Sixteen trash cans are provided in different areas of the park. There is a type of trash can for any kind of garbage, a type divided into two garbage categories (organic and inorganic), and a type divided into three garbage categories (organic, inorganic, and hazardous materials).

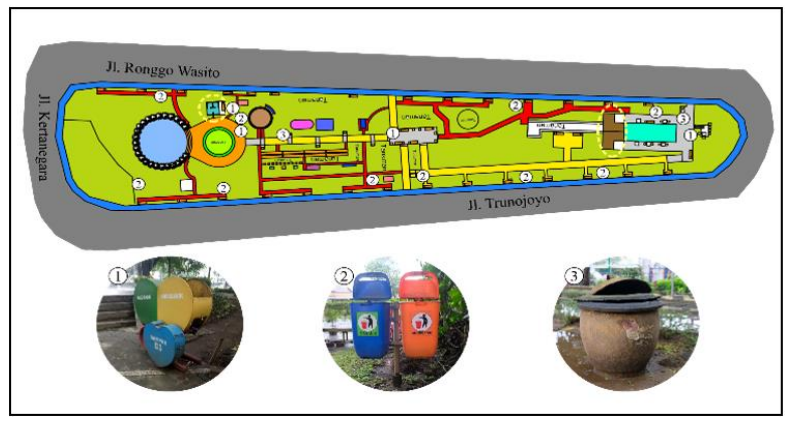

Figure 21 Types of trash cans inside the park

\subsubsection{Maintenance and comfort of sanitation facilities (FP_3)}

The amenities are averagely maintained. It needs to be cleaned regularly and be changed if it is necessary. Some trash cans need to be fixed and changed. Washroom and public toilets also need regular maintenance, so visitors can be comfortable while using it. The shower in the washroom is sometimes not working. Visitors sometimes ignore the rules to not urinate inside the washroom. The public toilet also needs regular cleaning so it can be free from unpleasant odor.

\subsubsection{Seating area facilities as a place to gather and socialize (FP_4)}

The seating area is one of the important places in the park. It can be a shelter for visitors from the sun, place where children and anyone can meet and hang out together.

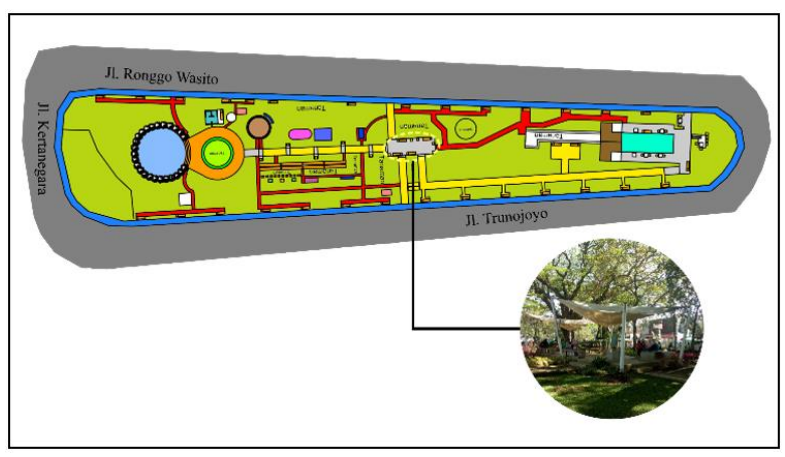

Figure 22 Park seating area

\subsubsection{Park's Natural Space}

The quality of the natural space of the park gets a good quality for child-friendliness. All variables in this indicator have a good quality and meet almost all of the standards and theories on the literature. Therefore, it can be said that this indicator is child-friendly.

Table 6. Qualitative result for the park's natural space

\begin{tabular}{|c|c|c|}
\hline Indicator & Variable & Quality \\
\hline \multirow{2}{*}{$\begin{array}{l}\text { Park } \\
\text { Vegetations }\end{array}$} & $\begin{array}{l}\text { Comfort with vegetation that shades the } \\
\text { park (RA_1) }\end{array}$ & Good \\
\hline & $\begin{array}{l}\text { Maintenance of park's vegetation giving } \\
\text { comfort (RA_2) }\end{array}$ & Good \\
\hline $\begin{array}{l}\text { Nature as } \\
\text { children } \\
\text { area }\end{array}$ & $\begin{array}{l}\text { Nature as the medium for learning and } \\
\text { playing for children (RA_3) }\end{array}$ & Good \\
\hline
\end{tabular}

\subsubsection{Comfort with vegetation that shades the park (RA_l)}

The playground's location must have a micro-climate which shaded by vegetation/buildings [7]. This park is already shaded with trees with large canopy. The trees' canopy is large enough to cover most of the park. The visitors can feel comfortable and refreshed in the park because they are shaded from the sunlight. 


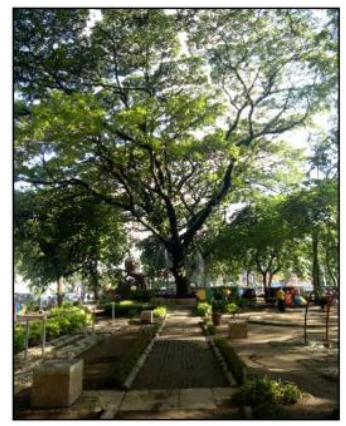

Figure 23 Trees with large canopy shading the park

\subsubsection{Maintenance of park's vegetation giving comfort (RA 2)}

Other vegetation, such as bushes and flowers, can be used to add the esthetic of a park or to divide areas of the park [14]. The availability of vegetation can also support the existing ecosystem. The availability of vegetation aside trees can eliminate a negative space. The vegetation can provide comfort to visitors, and overall it has adequately maintained. Visitors suggests that the park needs more colorful vegetation so the park can be even more aesthetic and beautiful.

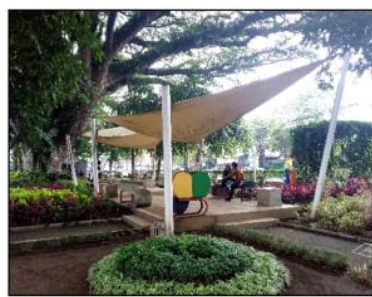

Figure 24. Small vegetation around the seating area

\subsubsection{Nature as the medium for learning and playing for children (RA_3)}

Nature gives the perfect environment for children to learn. The children can freely explore the park while playing with their friends or parents/guardians, asking their parents/guardians about the nature inside the park. Children can explore their imagination and creativity by building something out of sand or pretending to be a water bender.

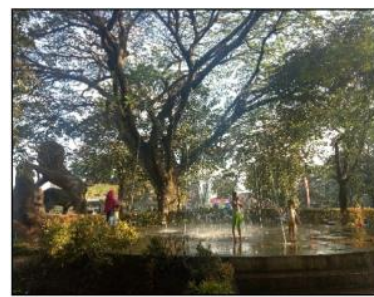

Figure 25 Children playing together in the water fountain play area

\subsubsection{Final Result of Qualitative Synthesis}

Taman Cerdas Trunojoyo gives open space to the community, especially for children, to spend time together with family and friends. Based on all the synthesis of every indicator, it can be said that the child-friendly quality of the park is Good. Therefore, Taman Cerdas Trunojoyo is childfriendly. However, some variables needed improvement to improve the child-friendly quality of Taman Cerdas Trunojoyo

\subsection{Quantitative Result}

Qualitative data is analyzed by using SPSS 24 . There are three steps in the analysis: 1) mean score analysis, 2) factor analysis, and 3) regression.

\subsubsection{Mean Score Analysis}

To categorize the average score into classes, the Sturgess formula is needed to determine the class's interval value. Three classes are used to categorize the average score, which is Bad, Decent, and Good. To determine the length of a class interval, the equation used is:

$$
\mathrm{i}=\mathrm{R} / \mathrm{K}=(4.54-2.72) / 3=1.82 / 3=0.6067=0.61
$$

Based on the formula, the result for the class interval value is 0.61. Based on the class interval value, we can obtain each class's scale. 'Bad' class has a scale of 2.72-3.32, 'Decent' class has a scale of 3.33-3.93, and 'Good' class has a scale of 3.94-4.54.

\subsubsection{Parents/Guardians of the Children Group}

According to parents/guardians of the Children, the quality of child-friendliness of Taman Cerdas Trunojoyo is Decent with the average mean score of 3.88 .

\subsection{Park Accessibility}

The quality of the accessibility of the park gets a decent quality for child-friendliness with an average score of 3.71. There is one variable that has a good quality (A_6), five variables have decent quality (A_1, A_2, A_4, A_5, and A_7), and one variable has bad quality (A_3). 
Table 7 Parents/guardians of children's perception of the park's accessibility

\begin{tabular}{|c|c|c|c|}
\hline Indicator & Variable & Score & Quality \\
\hline \multirow{5}{*}{$\begin{array}{l}\text { Ease and } \\
\text { Security of } \\
\text { Park } \\
\text { Accessibility }\end{array}$} & $\begin{array}{l}\text { Playground's location } \\
\text { security (A_1) }\end{array}$ & 3.87 & Decent \\
\hline & $\begin{array}{l}\text { Information system to park } \\
\text { gate (A_2) }\end{array}$ & 3.72 & Decent \\
\hline & $\begin{array}{l}\text { Park accessibility and } \\
\text { facilities for various groups } \\
\text { (A_3) }\end{array}$ & 3.24 & Bad \\
\hline & $\begin{array}{l}\text { Pedestrian care and comfort } \\
\text { (A_4) }\end{array}$ & 3.68 & Decent \\
\hline & $\begin{array}{l}\text { Pedestrian facility safety } \\
\text { (A_5) }\end{array}$ & 3.80 & Decent \\
\hline \multirow[t]{2}{*}{ Parking Lot } & $\begin{array}{l}\text { Parking lot availability } \\
\text { (A_6) }\end{array}$ & 3.97 & Good \\
\hline & Parking lot security (A_7) & 3.70 & Decent \\
\hline
\end{tabular}

\subsection{Park's Play, Leisure and Sport Facilities}

The quality of the play, leisure, and sports facilities of the park gets a decent quality for child-friendliness with an average score of 3.59. There is one variable that has a good quality (FRKO_6), five variables have decent quality (FRKO_1, FRKO_2, FRKO_4, FRKO_5, and FRKO_7), and one variable has bad quality (FRKO_3).

Table 8 Parents/guardians of children's perception of the park's play, leisure, and sport facilities

\begin{tabular}{|c|c|c|c|}
\hline Indicator & Variable & Score & Quality \\
\hline \multirow{5}{*}{$\begin{array}{l}\text { Playground } \\
\text { Facilities }\end{array}$} & $\begin{array}{l}\text { Children can practice social } \\
\text { skills and confidence } \\
\text { (FRKO_1) }\end{array}$ & 3.87 & Decent \\
\hline & $\begin{array}{l}\text { Physical safety of } \\
\text { playground facilities } \\
(\text { FRKO_2) }\end{array}$ & 3.50 & Decent \\
\hline & $\begin{array}{l}\text { Surfacing under playground } \\
\text { facilities (FRKO_3) }\end{array}$ & 2.72 & Bad \\
\hline & $\begin{array}{l}\text { Educative nature of facilities } \\
\text { (FRKO_4) }\end{array}$ & 3.64 & Decent \\
\hline & $\begin{array}{l}\text { Maintenance and comfort of } \\
\text { playground facilities } \\
\text { (FRKO_5) }\end{array}$ & 3.45 & Decent \\
\hline \multirow{2}{*}{$\begin{array}{l}\text { Park } \\
\text { Seating }\end{array}$} & $\begin{array}{l}\text { Seating facilities creates } \\
\text { social interactions (FRKO_6) }\end{array}$ & 4.12 & Good \\
\hline & $\begin{array}{l}\text { The comfort of seating } \\
\text { facilities (FRKO_7) }\end{array}$ & 3.80 & Decent \\
\hline
\end{tabular}

\subsection{Park Amenities}

The quality of the amenities of the park gets a good quality for child-friendliness with an average score of 3.99. Two variables have a good quality (FP_2 and FP_4), two variables have decent quality (FP_1 and FP_3), and no variable has bad quality.
Table 9 Parents/guardians of children's perception of the park's amenities

\begin{tabular}{|c|c|c|c|}
\hline Indicator & Variable & Score & Quality \\
\hline \multirow{3}{*}{$\begin{array}{l}\text { Sanitation } \\
\text { Facilities }\end{array}$} & $\begin{array}{l}\text { Availability of public toilets } \\
\text { and washrooms (FP_1) }\end{array}$ & 3.87 & Decent \\
\hline & $\begin{array}{l}\text { Availability of trash can } \\
\text { (FP 2) }\end{array}$ & 4.30 & Good \\
\hline & $\begin{array}{l}\text { Maintenance and comfort of } \\
\text { sanitation facilities (FP_3) }\end{array}$ & 3.74 & Decent \\
\hline $\begin{array}{l}\text { Park } \\
\text { Seating } \\
\text { Area }\end{array}$ & $\begin{array}{l}\text { Seating area facilities as a } \\
\text { place to gather and socialize } \\
\text { (FP_4) }\end{array}$ & 4.08 & Good \\
\hline
\end{tabular}

\subsection{Park's Natural Space}

The quality of the natural space of the park gets a good quality for child-friendliness with an average score of 4.33 . All variables in this indicator have good quality. Therefore, it can be said that this indicator is child-friendly.

Table 10 Parents/guardians of children's perception of the park's natural space

\begin{tabular}{|l|l|l|l|}
\hline Indicator & \multicolumn{1}{|c|}{ Variable } & Score & Quality \\
\hline \multirow{2}{*}{$\begin{array}{l}\text { Park } \\
\text { Vegetations }\end{array}$} & $\begin{array}{l}\text { Comfort with vegetation that } \\
\text { shades the park (RA_1) }\end{array}$ & 4.54 & Good \\
\cline { 2 - 4 } & $\begin{array}{l}\text { Maintenance of park's } \\
\text { vegetation giving comfort } \\
\text { (RA_2) }\end{array}$ & 4.36 & Good \\
\hline $\begin{array}{l}\text { Nature as } \\
\text { children } \\
\text { area }\end{array}$ & $\begin{array}{l}\text { Nature as the medium for } \\
\text { learning and playing for } \\
\text { children (RA_3) }\end{array}$ & 4.09 & Good \\
\hline
\end{tabular}

\subsubsection{Children Group}

According to children, the quality of child-friendliness of Taman Cerdas Trunojoyo is Decent with the average mean score of 3.77 .

\subsection{Parks Acccessibility}

The quality of the accessibility of the park gets a decent quality for child-friendliness with an average mean score of 3.57. All variables have a decent quality.

Table 11 Children's perception of the park's accessibility

\begin{tabular}{|l|l|c|c|}
\hline Indicator & \multicolumn{1}{|c|}{ Variable } & Mean & Quality \\
\hline $\begin{array}{l}\text { Ease and } \\
\text { Security of }\end{array}$ & $\begin{array}{l}\text { Playground's location } \\
\text { security (A_1) }\end{array}$ & 3.62 & Decent \\
\cline { 2 - 4 } Accessibility & $\begin{array}{l}\text { Park accessibility and } \\
\text { facilities for various } \\
\text { groups (A_2) }\end{array}$ & 3.52 & Decent \\
\hline
\end{tabular}




\subsection{Park's Play, Leisure and Sport Facilities}

The quality of the play, leisure, and sports facilities of the park gets a decent quality for child-friendliness with a mean score of 3.68 .

Table 12 Children's perception of the park's play, leisure, and sport facilities

\begin{tabular}{|l|l|l|l|}
\hline Aspect & \multicolumn{1}{|c|}{ Variable } & Mean & Quality \\
\hline $\begin{array}{l}\text { Playground } \\
\text { Facilities }\end{array}$ & $\begin{array}{l}\text { Children can practice social } \\
\text { skills and confidence } \\
\text { (FRKO_1) }\end{array}$ & 3.68 & Decent \\
\hline
\end{tabular}

\subsection{Park Amenities}

The quality of the park amenities gets a good quality for child-friendliness with a mean score of 4.38 .

Table 13 Children's perception of the park amenities

\begin{tabular}{|l|l|l|l|}
\hline Aspect & \multicolumn{1}{|c|}{ Variable } & Mean & Quality \\
\hline $\begin{array}{l}\text { Park } \\
\text { Seating } \\
\text { Area }\end{array}$ & $\begin{array}{l}\text { Seating area facilities as a } \\
\text { place to gather and socialize } \\
\text { (FP_1) }\end{array}$ & 4.38 & Good \\
\hline
\end{tabular}

\subsection{Park's Natural Space}

The quality of the natural space of the park gets a decent quality for child-friendliness with a mean score of 3.60.

Table 14 Children's perception of the park's natural space

\begin{tabular}{|l|l|l|l|}
\hline Aspect & \multicolumn{1}{|c|}{ Variable } & Mean & Quality \\
\hline $\begin{array}{l}\text { Nature as } \\
\text { children } \\
\text { area }\end{array}$ & $\begin{array}{l}\text { Nature as the medium for } \\
\text { learning and playing for } \\
\text { children (RA_1) }\end{array}$ & 3.60 & Decent \\
\hline
\end{tabular}

\subsubsection{Factor Analysis}

Factor analysis is used to find out what factors influenced the quality of child-friendly in Taman Cerdas Trunojoyo. Factors are formed from the results of data reduction.

The average communalities extraction value is $>0.5$ $(>50 \%)$. The factors can be explained by the variables so that the analysis can proceed to the next step. However, there is a variable that is not strong enough to explain a factor, which is "Seating facilities create social interactions."

\section{Table 15 Communalities}

\begin{tabular}{|l|l|l|}
\hline \multicolumn{1}{|c|}{ Variable } & Initial & Extraction \\
\hline Playground's location security & 1.000 & .749 \\
\hline Information system to park gate & 1.000 & .594 \\
\hline $\begin{array}{l}\text { Park accessibility and facilities for } \\
\text { various groups }\end{array}$ & 1.000 & .609 \\
\hline
\end{tabular}

\begin{tabular}{|l|l|l|}
\hline \multicolumn{1}{|c|}{ Variable } & Initial & Extraction \\
\hline $\begin{array}{l}\text { Pedestrian ways maintenance and } \\
\text { comfort }\end{array}$ & 1.000 & .594 \\
\hline Pedestrian ways safety & 1.000 & .731 \\
\hline Parking lot availability & 1.000 & .821 \\
\hline Parking lot security & 1.000 & .857 \\
\hline $\begin{array}{l}\text { Children can practice social skills and } \\
\text { confidence }\end{array}$ & 1.000 & .606 \\
\hline Physical safety of playground facilities & 1.000 & .640 \\
\hline Surfacing under playground facilities & 1.000 & .505 \\
\hline Educative nature of facilities & 1.000 & .705 \\
\hline $\begin{array}{l}\text { Maintenance and comfort of playground } \\
\text { facilities }\end{array}$ & 1.000 & .735 \\
\hline $\begin{array}{l}\text { Seating facilities creates social } \\
\text { interactions }\end{array}$ & 1.000 & .431 \\
\hline $\begin{array}{l}\text { Maintenance and comfort of seating } \\
\text { facilities }\end{array}$ & 1.000 & .568 \\
\hline $\begin{array}{l}\text { Availability of public toilets and } \\
\text { washrooms }\end{array}$ & 1.000 & .660 \\
\hline Availability of trash can & 1.000 & .730 \\
\hline $\begin{array}{l}\text { Maintenance and comfort of sanitation } \\
\text { facilities }\end{array}$ & 1.000 & .691 \\
\hline $\begin{array}{l}\text { Seating area facilities as a place to } \\
\text { gather and socialize }\end{array}$ & 1.000 & .509 \\
\hline $\begin{array}{l}\text { Comfort with vegetation that shades the } \\
\text { park }\end{array}$ & 1.000 & .622 \\
\hline $\begin{array}{l}\text { Maintenance of park's vegetation giving } \\
\text { comfort }\end{array}$ & 1.000 & .726 \\
\hline $\begin{array}{l}\text { Nature as the medium for learning and } \\
\text { playing for children }\end{array}$ & 1.000 & .663 \\
\hline
\end{tabular}

To determine how many factors are formed, it is necessary to check the Eigenvalue. If the Eigenvalue is $>1$, then the component can be used as a factor. Based on Fig. 42, 6 components have an Eigenvalue above 1.

Table 16 Eigenvalues of the Components

\begin{tabular}{|c|c|c|c|}
\hline \multirow{2}{*}{ Component } & \multicolumn{3}{|c|}{ Initial Eigenvalues } \\
\cline { 2 - 4 } & Total & \% of variance & Cumulative \% \\
\hline 1 & 6.453 & 30.729 & 30.729 \\
\hline 2 & 2.221 & 10.578 & 41.306 \\
\hline 3 & 1.737 & 8.272 & 49.579 \\
\hline 4 & 1.211 & 5.764 & 55.343 \\
\hline 5 & 1.080 & 5.145 & 60.488 \\
\hline 6 & 1.044 & 4.973 & 65.461 \\
\hline 7 & 0.993 & 4.729 & 70.190 \\
\hline 8 & 0.880 & 4.192 & 74.382 \\
\hline 9 & 0.845 & 4.026 & 78.408 \\
\hline 10 & 0.759 & 3.612 & 82.020 \\
\hline 11 & 0.590 & 2.810 & 84.830 \\
\hline 12 & 0.522 & 2.487 & 87.317 \\
\hline 13 & 0.459 & 2.183 & 89.501 \\
\hline 14 & 0.416 & 1.979 & 91.480 \\
\hline 15 & 0.401 & 1.907 & 93.387 \\
\hline 16 & 0.342 & 1.629 & 95.016 \\
\hline 17 & 0.313 & 1.489 & 96.505 \\
\hline 18 & 0.219 & 1.042 & 97.546 \\
\hline 19 & 0.213 & 1.015 & 98.561 \\
\hline 20 & 0.167 & 0.793 & 99.355 \\
\hline 21 & 0.136 & 0.645 & 100.000 \\
\hline & & & \\
\hline
\end{tabular}


To determine the variables in each factor, it is necessary to see the results of loading factors from the Rotated Component Matrix (Table 17).

Table 17 Rotated Component Matrix

\begin{tabular}{|l|l|l|l|l|l|l|}
\hline \multirow{2}{*}{ Variable } & \multicolumn{2}{l}{ Component } & \multicolumn{5}{l|}{} \\
\hline & $\mathbf{1}$ & $\mathbf{2}$ & $\mathbf{3}$ & $\mathbf{4}$ & $\mathbf{5}$ & $\mathbf{6}$ \\
\hline A_3 & 0.715 & & & & & \\
\hline FRKO_5 & 0.688 & & & & & \\
\hline FRKO_3 & 0.646 & & & & & \\
\hline FRKO_7 & 0.608 & & & & & \\
\hline FP_3 & 0.566 & & & & & \\
\hline FRKO_4 & & 0.682 & & & & \\
\hline RA_3 & & 0.652 & & & & \\
\hline FP_4 & & 0.597 & & & & \\
\hline FRKO_6 & & 0.543 & & & & \\
\hline FP_1 & & 0.490 & & & & \\
\hline A_5 & & & 0.816 & & & \\
\hline A_4 & & & 0.678 & & & \\
\hline A_2 & & & 0.560 & & & \\
\hline FRKO_1 & & & 0.553 & & & \\
\hline RA_2 & & & & 0.795 & & \\
\hline RA_1 & & & & 0.756 & & \\
\hline FP_2 & & & & 0.686 & & \\
\hline A_6 & & & & & 0.896 & \\
\hline A_5 & & & & & 0.888 & \\
\hline A_1 & & & & & & 0.805 \\
\hline FRKO_2 & & & & & & 0.579 \\
\hline
\end{tabular}

Based on table 17, the first factor has five variables, the second factor has four variables, the third factor has four variables, the fourth factor has three variables, the fifth factor has two variables, and the sixth factor has two variables.

Table 18 Group of Factors

\begin{tabular}{|c|c|c|}
\hline Factor & Variable & $\begin{array}{l}\text { Loading } \\
\text { Factor }\end{array}$ \\
\hline \multirow{5}{*}{$\begin{array}{l}\text { Park } \\
\text { Facilities }\end{array}$} & $\begin{array}{l}\text { Park accessibility and facilities for } \\
\text { various groups }\end{array}$ & 0.715 \\
\hline & $\begin{array}{l}\text { Maintenance and comfort of playground } \\
\text { facilities }\end{array}$ & 0.688 \\
\hline & Surfacing under playground facilities & 0.646 \\
\hline & $\begin{array}{l}\text { Maintenance and comfort of seating } \\
\text { facilities }\end{array}$ & 0.608 \\
\hline & $\begin{array}{l}\text { Maintenance and comfort of sanitation } \\
\text { facilities }\end{array}$ & 0.566 \\
\hline \multirow{5}{*}{$\begin{array}{l}\text { Park as the } \\
\text { Place of } \\
\text { Activities }\end{array}$} & Educative nature of facilities & 0.682 \\
\hline & $\begin{array}{l}\text { Nature as the medium for learning and } \\
\text { playing for children }\end{array}$ & 0.652 \\
\hline & $\begin{array}{l}\text { Seating area facilities as a place to gather } \\
\text { and socialize }\end{array}$ & 0.597 \\
\hline & $\begin{array}{l}\text { Seating facilities creates social } \\
\text { interactions }\end{array}$ & 0.543 \\
\hline & $\begin{array}{l}\text { Availability of public toilets and } \\
\text { washrooms }\end{array}$ & 0.490 \\
\hline \multirow{2}{*}{$\begin{array}{l}\text { Ease of } \\
\text { Visitor } \\
\text { Accessibility }\end{array}$} & Pedestrian ways safety & 0.816 \\
\hline & $\begin{array}{l}\text { Pedestrian ways maintenance and } \\
\text { comfort }\end{array}$ & 0.678 \\
\hline
\end{tabular}

\begin{tabular}{|c|c|c|}
\hline Factor & Variable & $\begin{array}{l}\text { Loading } \\
\text { Factor }\end{array}$ \\
\hline & Information system to park gate & 0.560 \\
\hline & $\begin{array}{l}\text { Children can practice social skills and } \\
\text { confidence }\end{array}$ & 0.553 \\
\hline \multirow{3}{*}{ Park Comfort } & $\begin{array}{l}\text { Maintenance of park's vegetation giving } \\
\text { comfort }\end{array}$ & 0.795 \\
\hline & $\begin{array}{l}\text { Comfort with vegetation that shades the } \\
\text { park }\end{array}$ & 0.756 \\
\hline & Availability of trash can & 0.686 \\
\hline \multirow{2}{*}{ Parking Lot } & Parking lot security & 0.896 \\
\hline & Parking lot availability & 0.888 \\
\hline \multirow{2}{*}{$\begin{array}{l}\text { Playground } \\
\text { Area Safety }\end{array}$} & Playground's location security & 0.805 \\
\hline & Physical safety of playground facilities & 0.579 \\
\hline
\end{tabular}

\subsubsection{Regression}

Regression is used to determine which factor that influence the child-friendly quality of Taman Cerdas Trunojoyo the most. The dependent variable is the average child-friendly quality of Taman Cerdas Trunojoyo per respondent group. The independent variable is the factor value that formed from factor analysis. The results of the regression analysis are as follows.

\subsubsection{Parents/Guardians of the Children Group}

Based on Table 19, the R Square value is 0.721 . This shows that the independent variable can explain $72.1 \%$ of the dependent variable. The remaining $27.9 \%$ is influenced or explained by other variables not included in this research model.

Table 19 Regression analysis for parents/guardians of children group

\begin{tabular}{|c|c|c|c|c|}
\hline \multicolumn{5}{|c|}{ Model Summary $^{\mathbf{b}}$} \\
\hline Model & $\boldsymbol{R}$ & R Square & Adj. R Square & Std. Error \\
\hline 1 & $0.849^{\mathrm{a}}$ & 0.721 & 0.697 & 0.284 \\
\hline
\end{tabular}

a. Predictors: (Constant), independent variables

b. Dependent variable

Based on Table 20, the conclusion is that the independent variables simultaneously influence the dependent variable because the significance value is $0.000>0.05$. All independent variables affect the dependent variable because of the value of Fcount (29.701) > Ftable (2.23).

Table 20 Regression analysis for parents/guardians of children group

\begin{tabular}{|c|c|c|c|c|c|}
\hline \multicolumn{6}{|l|}{ ANOVA $^{a}$} \\
\hline Model & $\begin{array}{l}\text { Sum of } \\
\text { Squares }\end{array}$ & $d f$ & $\begin{array}{l}\text { Mean } \\
\text { Square }\end{array}$ & $F$ & Sig. \\
\hline Regression & 14.370 & 6 & 2.395 & 29.701 & $0.000^{\mathrm{b}}$ \\
\hline Residual & 5.564 & 69 & 0.081 & & \\
\hline Total & 19.934 & 75 & & & \\
\hline
\end{tabular}

a. Dependent variable

b. Predictors: (Constant), independent variables 
Based on Table 21, all factors have a significance of 0.000 , which means it is below 0.05 . This indicates that all factors influence the child-friendly quality of Taman Cerdas Trunojoyo. The most influential factor is Park Facilities because this factor has the largest tcount value $\left(\mathrm{t}_{\text {count }}(7.547)\right.$ $>\mathrm{t}_{\text {table }}(1.667)$

Table 21 Regression analysis for parents/guardians of children group

\begin{tabular}{|l|c|c|c|l|l|}
\hline \multirow{2}{*}{ Model } & \multicolumn{2}{|c|}{ Unstd. Coeff. } & $\begin{array}{c}\text { Std. } \\
\text { Coeff } \\
\text {. }\end{array}$ & \multicolumn{1}{|c|}{ t } & \multirow{2}{*}{ Sig. } \\
\cline { 2 - 5 } & \multicolumn{1}{|c|}{$\boldsymbol{B}$} & $\begin{array}{c}\text { Std. } \\
\text { Error }\end{array}$ & Beta & & \\
\hline (Constant) & 3.882 & 0.033 & & 119.164 & 0.000 \\
\hline Park Facilities & 0.247 & 0.033 & 0.480 & 7.547 & 0.000 \\
\hline $\begin{array}{l}\text { Park as the } \\
\text { Place of } \\
\text { Activities }\end{array}$ & 0.241 & 0.033 & 0.467 & 7.338 & 0.000 \\
\hline $\begin{array}{l}\text { Ease of Visitor } \\
\text { Accessibility }\end{array}$ & 0.155 & 0.033 & 0.301 & 4.739 & 0.000 \\
\hline Park Comfort & 0.127 & 0.033 & 0.246 & 3.871 & 0.000 \\
\hline Parking Lot & 0.124 & 0.033 & 0.241 & 3.791 & 0.000 \\
\hline $\begin{array}{l}\text { Playground } \\
\text { Area Safety }\end{array}$ & 0.129 & 0.033 & 0.251 & 3.948 & 0.000 \\
\hline
\end{tabular}

\subsubsection{Children Group}

Based on Table 22, the R Square value is 0.844 (84.4\%). This shows that the independent variable can explain $77.2 \%$ of the dependent variable. The remaining $22.8 \%$ is influenced or explained by other variables not included in this research model.

Table 22 Regression analysis for children group

\begin{tabular}{|c|c|c|c|c|}
\hline \multicolumn{5}{|c|}{ Model Summary $^{\mathbf{b}}$} \\
\hline Model & $\boldsymbol{R}$ & R Square & Adj. R Square & Std. Error \\
\hline 1 & $0.919^{\mathrm{a}}$ & 0.844 & 0.831 & 0.204 \\
\hline
\end{tabular}

a. Predictors: (Constant), Independent variables

b. Dependen variable

Based on Table 23, the conclusion is that the independent variables simultaneously influence the dependent variable because the significance value is $0.000>0.05$. All independent variables affect the dependent variable because of the value of $F_{\text {count }}(63.848)>F_{\text {table }}(2.23)$.

Table 23 Regression analysis for children group

\begin{tabular}{|c|c|c|c|c|c|}
\hline \multicolumn{6}{|l|}{ ANOVA $^{a}$} \\
\hline Model & $\begin{array}{l}\text { Sum of } \\
\text { Squares }\end{array}$ & $d f$ & $\begin{array}{l}\text { Mean } \\
\text { Square }\end{array}$ & $F$ & Sig. \\
\hline Regression & 13.348 & 5 & 2.670 & 63.848 & $0.000^{\mathrm{b}}$ \\
\hline Residual & 2.467 & 59 & 0.042 & & \\
\hline Total & 15.815 & 64 & & & \\
\hline
\end{tabular}

a. Dependent variable

b. Predictors: (Constant), Independent variables
Based on Table 24, all factors have a significance of 0.000 , which means it is below 0.05 . This indicates that all factors influence the child-friendly quality of Taman Cerdas Trunojoyo. The most influential factor is Park Facilities because this factor has the largest $\mathrm{t}_{\text {count }}$ value $\left(\mathrm{t}_{\text {count }}(5.190)\right.$ $\left.>t_{\text {table }}(2.001)\right)$

Table 24 Regression analysis for children group

\begin{tabular}{|l|c|c|c|c|c|}
\hline \multirow{2}{*}{ Model } & \multicolumn{2}{|c|}{ Unstd. Coeff. } & $\begin{array}{c}\text { Std. } \\
\text { Coeff. }\end{array}$ & \multirow{2}{*}{ t } & \multirow{2}{*}{ Sig. } \\
\cline { 2 - 5 } & $\boldsymbol{B}$ & $\begin{array}{c}\text { Std. } \\
\text { Error }\end{array}$ & Beta & & \\
\hline (Constant) & .414 & .214 & & 1.940 & .057 \\
\hline $\begin{array}{l}\text { Playground's location } \\
\text { security }\end{array}$ & .155 & .045 & .209 & 3.409 & .001 \\
\hline $\begin{array}{l}\text { Park accessibility and } \\
\text { facilities for various } \\
\text { groups }\end{array}$ & .164 & .035 & .274 & 4.679 & .000 \\
\hline $\begin{array}{l}\text { Children can practice } \\
\text { social skills and } \\
\text { confidence }\end{array}$ & .238 & .046 & .370 & 5.190 & .000 \\
\hline $\begin{array}{l}\text { Seating area facilities } \\
\text { as a place to gather } \\
\text { and socialize }\end{array}$ & .209 & .042 & .275 & 4.974 & .000 \\
\hline $\begin{array}{l}\text { Nature as the medium } \\
\text { for learning and } \\
\text { playing for children }\end{array}$ & .131 & .037 & .222 & 3.496 & .001 \\
\hline $\begin{array}{l}\text { Playground's location } \\
\text { security }\end{array}$ & 0.129 & 0.033 & 0.251 & 3.948 & 0.000 \\
\hline
\end{tabular}

\subsection{Mixed-Method Result}

This research is using a mixed-method that compares the analysis and synthesis of qualitative and quantitative methods. After comparing both of the results, a new combined synthesis will be obtained. This gives a new synthesis between the results of qualitative and quantitative analysis and synthesis.

\subsubsection{Parents/Guardians of the Children Group}

There are three factors with decent quality and three other factors with good quality. If all factors are combined, then the final synthesis for the child-friendly quality of Taman Cerdas Trunojoyo, according to the parents/guardians of the child, is Good. This means that Taman Cerdas Trunojoyo is a child-friendly park. The factor which has the most influence on the park's child-friendliness is Park Facilities.

Table 25 Combined synthesis of parents/guardians of the children group

\begin{tabular}{|l|l|l|l|}
\hline \multirow{2}{*}{ Factor } & Synthesis & $\begin{array}{l}\text { Combined } \\
\text { Synthesis }\end{array}$ \\
\cline { 2 - 3 } & Qualitative & Quantitative & Decent \\
\hline Park Facilities & Decent & Decent & Good \\
\hline $\begin{array}{l}\text { Park as the Place } \\
\text { of Activities }\end{array}$ & Good & Good & Decent \\
\hline $\begin{array}{l}\text { Ease of Visitor } \\
\text { Accessibility }\end{array}$ & Decent & Decent & \\
\hline
\end{tabular}




\begin{tabular}{|l|l|l|l|}
\hline \multirow{2}{*}{ Factor } & \multicolumn{2}{|l|}{ Synthesis } & $\begin{array}{l}\text { Combined } \\
\text { Synthesis }\end{array}$ \\
\cline { 2 - 4 } & Qualitative & Quantitative & Good \\
\hline Park Comfort & Good & Good & Good \\
\hline Parking Lot & Good & Good & Decent \\
\hline $\begin{array}{l}\text { Playground Area } \\
\text { Safety }\end{array}$ & Decent & Decent & Good \\
\hline Average
\end{tabular}

\subsubsection{Children Group}

There are three variables with decent quality and two other variables with good quality. If the results of all variables are combined, the final synthesis for the child-friendly quality of Taman Cerdas Trunojoyo, according to the children, is fairly child-friendly.

Table 26 Combined synthesis children group

\begin{tabular}{|c|c|c|c|}
\hline \multirow{2}{*}{ Variable } & \multicolumn{2}{|l|}{ Synthesis } & \multirow{2}{*}{$\begin{array}{l}\text { Combined } \\
\text { Synthesis }\end{array}$} \\
\hline & Qualitative & Quantitative & \\
\hline $\begin{array}{l}\text { Playground's location } \\
\text { security }\end{array}$ & Decent & Decent & Decent \\
\hline $\begin{array}{l}\text { Park accessibility and } \\
\text { facilities for various } \\
\text { groups }\end{array}$ & $\mathrm{Bad}$ & Decent & Decent \\
\hline $\begin{array}{l}\text { Children can practice } \\
\text { social skills and } \\
\text { confidence }\end{array}$ & Decent & Decent & Decent \\
\hline $\begin{array}{l}\text { Seating area facilities } \\
\text { as a place to gather } \\
\text { and socialize }\end{array}$ & Good & Good & Good \\
\hline $\begin{array}{l}\text { Nature as the } \\
\text { medium for learning } \\
\text { and playing for } \\
\text { children }\end{array}$ & Good & Decent & Good \\
\hline \multicolumn{3}{|l|}{ Average } & Decent \\
\hline
\end{tabular}

\section{CONCLUSION}

Based on the research question, "How is the quality of the Taman Cerdas Trunojoyo with the Child-Friendly Criteria approach?", a mixed-method analysis was conducted to find the answer. Based on the results of qualitative and quantitative research regarding the child-friendly quality of Taman Pintar Trunojoyo, there are differences in the quality ratings between respondent groups, Parents/Guardians of Children, and Children. According to Parents/Guardians of Children, the quality of the Taman Cerdas Trunojoyo is Good, so it is child-friendly. However, according to the Children, the child-friendly quality of this park is decent enough for child-friendliness. These results are supported by quantitative and qualitative analysis and synthesis.

Based on the factor analysis result, six factors affected the child-friendly quality of Taman Cerdas Trunojoyo, according to parents/guardians of children. These factors are Park Facilities, Park as the Place of Activities, Ease of Visitor Accessibility, Park Comfort, Parking Lot, and Playground Area Safety.
Based on the results of the regression analysis, all of the factors that had been identified significantly affected the child-friendly quality of Taman Cerdas Trunojoyo, according to parents/guardians of the children. According to children, all variables also significantly affected the quality of the park as well. However, the most influential factor in the child-friendly quality of Taman Cerdas Trunojoyo is "Park Facilities." The most influential variable, according to children, is "Children can practice social skills and confidence."

\section{REFERENCES}

[1] Indonesia. Permen PU No. 05/PRT/M/2008. Jakarta: Minister of Public Works and Public Housing; 2008.

[2] Ratri, Nurlayla. Hat-Trick Tiga Tahun Berturutturut Kota Malang Dapat Penghargaan Ini. Jatim Times. [Online] Available from:

https://jatimtimes.com/baca/176101/20180724/221500/ hattrick-tiga-tahun-berturutturut-kota-malang-dapatpenghargaan-ini/ [Accessed 19th December 2018].

[3] Carr, Stephen et al. Public Space. Google Books. "https://books.google.co.id/books/about/Public_Space.h tml?id=pjo4AAAAIAAJ\&printsec $=$ frontcover \&source $=\mathrm{kp} \_$read_button\&redir_esc $=\mathrm{y} \# \mathrm{v}=$ onepage $\& \mathrm{q} \& \mathrm{f}=$ false . USA: Cambridge University Press; 1992.

[4] Mulyandari, Hestin. Pengantar Arsitektur Kota. Yogyakarta: Penerbit ANDI; 2011.

[5] UNICEF. UNICEF Child-Friendly Cities and Communities Handbook. UNICEF. "https://www.unicef.org/eap/reports/child-friendlycities-and-communities-handbook". 2018.

[6] Indonesia. Permen PPPA No. 12 Tahun 2011 Tentang Indikator Kabupaten/Kota Layak Anak. Jakarta: Minister of Womens' Empowerment and Child Protection; 2011.

[7] Baskara, Medha. "Prinsip Pengendalian Perancangan Taman Bermain Anak di Ruang Publik," in Jurnal Lanskap Indonesia Vol. 3 Number 1 (2011) 27-34.

[8] Neuwman, W. Lawrence. Social Research Methods: Qualitative and Quantitative Approaches 7th Edition. Edinburgh: Pearson Education Ltd.; 2014.

[9] Sugiyono. Metode Penelitian Bisnis: Pendekatan Kuantitatif, Kualitatif, Kombinasi, dan R\&D Edisi Ketiga. Bandung: Penerbit Alfabeta.; 2018. 
[10] Malang City. RDTR dan Peraturan Zonasi BWP Malang Tengah Tahun 2016-2036: Bab XI Bagian

Kedua. Malang City: The Mayor of Malang; 2016.

[11] Indonesia. Permen PU No. 03/PRT/M/2014.

Jakarta: Minister of Public Works and Public Housing; 2008.

[12] The Play Inspection Company \& Wicksteed Leisure. An Essential Guide to BS EN 1176 and BS EN 1177. Dorset: The Play Inspection Company \& Wicksteed Leisure; 2008.

[13] U.S. Consumer Product Safety Commision. Public Playground Safety Handbook. Maryland: U.S.

Consumer Product Safety Commision; 2015.

[14] Hakim, Rustam. Komponen Perancangan Arsitektur Lansekap: Prinsip-Unsur dan Aplikasi

Desain. Jakarta: PT. Bumi Aksara; 2012. 